\title{
NOTES
}

\section{FIRST RECORDS OF THE ASIAN ROSY-FINCH IN ALASKA AND NORTH AMERICA}

\author{
ISAAC J. HELMERICKS, 2074 North Rush Circle, Palmer, Alaska 99645; \\ isaac.helmericks@gmail.com
}

On 30 December 2011 I found and photographed an Asian Rosy-Finch (Leucosticte arctoa) on Adak Island, in the central Aleutian Islands, Alaska. At that time and for the next five years this bird provided the only record of the species for North America. In 2016, however, a photo surfaced of a bird that had been seen in October 2008 at Gambell, St. Lawrence Island, revealing it too to have been an Asian Rosy-Finch. Thus at the close of 2016 there were two records of this species within the political limits of Alaska and North America.

From the 1940s to the late 1990s, Adak Island was home to a large U.S. navy base. (If Adak Naval Station had been an incorporated town or city instead of a military installation, its peak population during the Cold War years of $6000+$ residents would have qualified it as one of the half dozen largest cities in Alaska.) Adak Naval Station was demobilized in 1997, and ownership of the extensive infrastructure that remained, including a network of roads on the northeast portion of the island, was transferred to the Aleut Corporation, one of 13 Alaska Native regional corporations established under the Alaska Native Claims Settlement Act in 1971. In 2001 the Aleut Corporation incorporated the city of Adak, and at the 2010 census its population comprised 326 people. Most of Adak Island-all but the land constituting the former military base - remains a part of the Alaska Maritime National Wildlife Refuge. Reeve Aleutian Airways provided air service for almost 70 years but ended passenger service to the Aleutians in December 2000, in part a casualty of the navy's departure. In 2007 I moved to Adak as the customer service manager for Alaska Airlines.

During regular year-round transects for birds on the Adak road system from 2007 to 2012, I came across on 30 December 2011 a small flock of four Snow Buntings (Plectrophenax nivalis) and a single dark finch, which I identified as an Asian Rosy-Finch by its raspberry-pink body and golden-brown nape and crown (Figures 1-3) - rather than one of the numerous resident Gray-crowned Rosy-Finches ( $L$. tephrocotis griseonucha), which at Adak typically do not flock in winter with other species. I was able to study the bird for a half hour before the flock flew off. The golden-brown color of the nape came up to the crown, where it diffused into the black face, auriculars, lores, chin, and throat. The bird was more the size of the Snow Buntings, smaller overall - head, bill, wings, and tail — than subspecies griseonucha of the Gray-crowned Rosy-Finch. Most of its breast, flanks, rump, undertail coverts, and lesser and median coverts were very pink. Five color photographs and the details of this sighting were submitted to the Alaska Checklist Committee, which unanimously accepted it as a first record for Alaska (Gibson et al. 2013).

Another Asian Rosy-Finch, seen 25-26 October 2008 at Gambell, St. Lawrence Island, by Hansen Irrigoo and Gerard Koonooka, came to light in August 2016, when an archived photograph (Figure 4) was closely examined and the bird identified by the Alaska Checklist Committee (in litt., 2016) and by P. E. Lehman (in litt., 2016). To date the only St. Lawrence Island record of the Gray-crowned Rosy-Finch is of a female collected at Savoonga in June 1988 by R. L. Rausch. It is L. tephrocotis tephrocotis, the subspecies that nests in the Brooks Range and is a rare breeder as far west as the Seward Peninsula (see Kessel 1989).

The Asian Rosy-Finch is a relatively large, long-winged finch of south-central Siberia, northern Mongolia, northern China, and the Russian Far East (see Vaurie 


\section{NOTES}

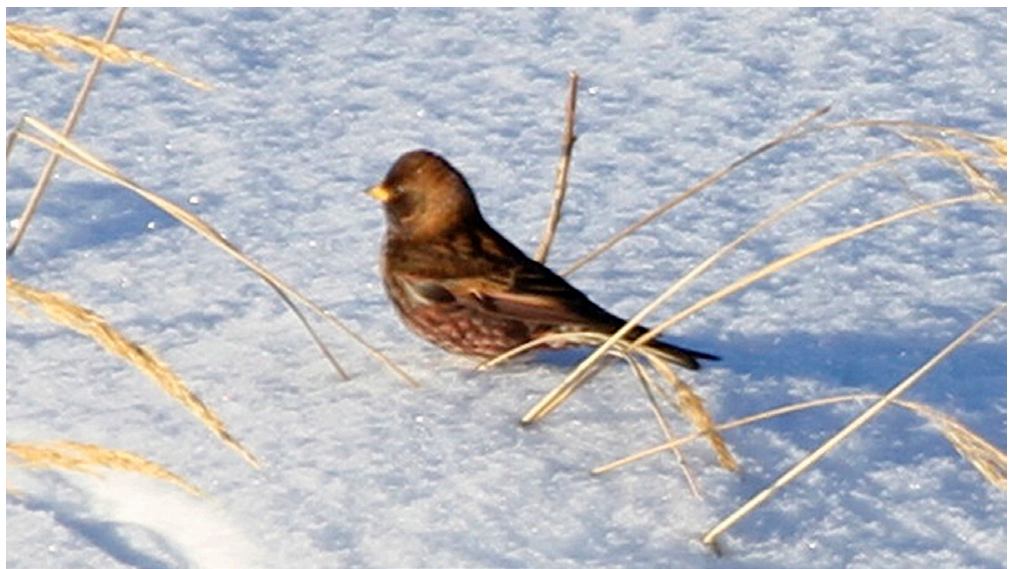

Figure 1. Asian Rosy-Finch on Adak Island, Alaska, 30 December 2011.

Photo by Isaac J. Helmericks

1959, Brazil 2009). In summer, the species breeds in rocky tundra and in mountains above tree line. During the cold winter months the birds retreat to grassy lowlands and snow-free coastal areas. Dickinson and Christidis (2014) and Clement and Arkhipov (2017) recognized five subspecies. Four are largely resident, making only seasonal elevational movements. Subspecies brunneonucha, the bird of the Russian Far East,

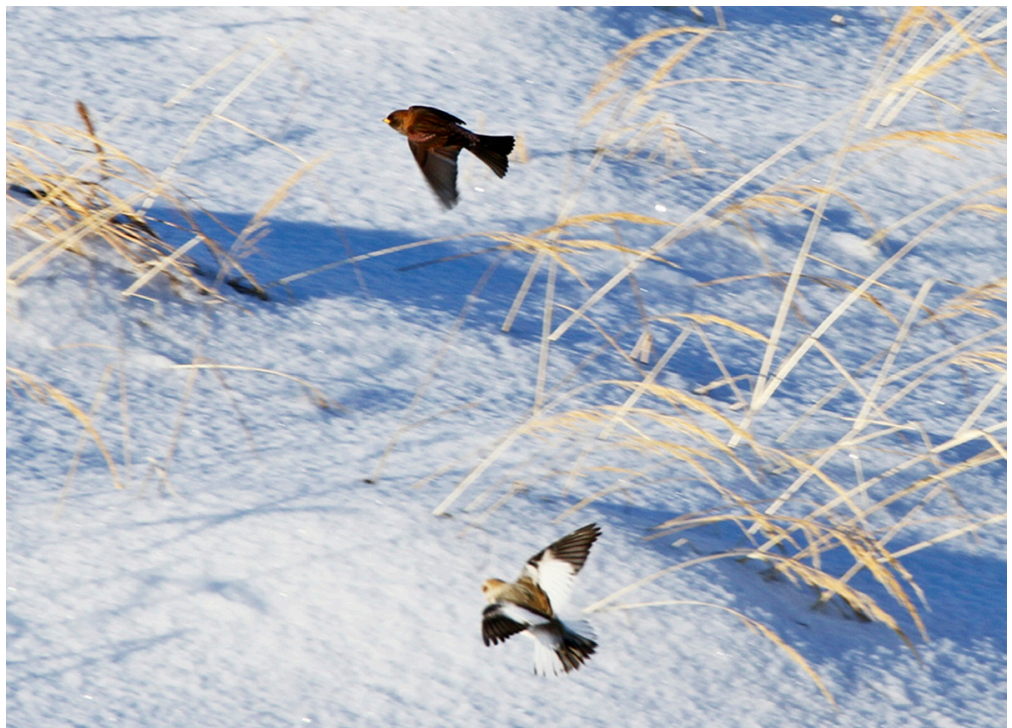

Figure 2. Asian Rosy-Finch in flight with Snow Bunting on Adak Island, Alaska, 30 December 2011. 


\section{NOTES}

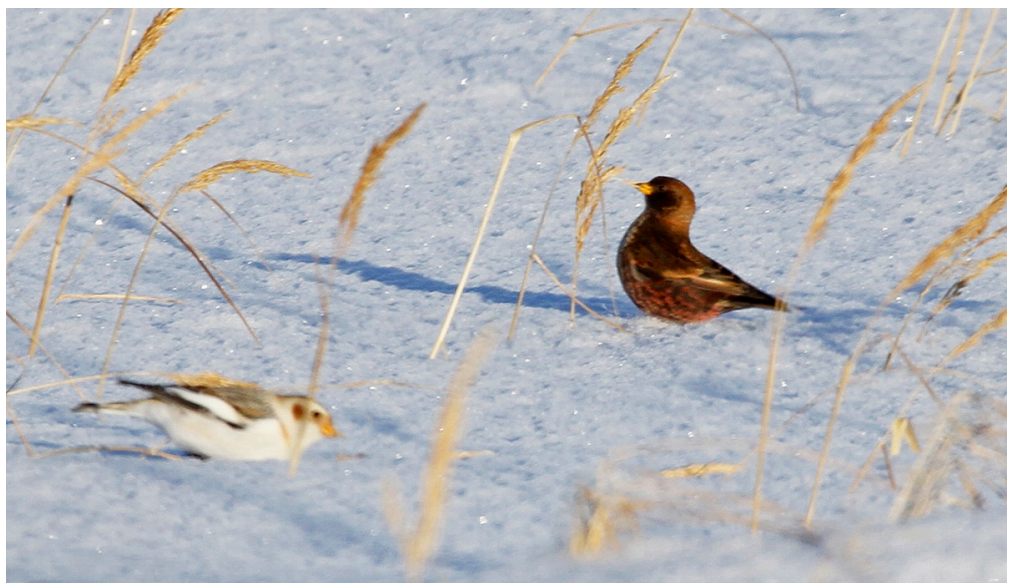

Figure 3. Asian Rosy-Finch with Snow Bunting on Adak Island, Alaska, 30 December 2011.

Photo by Isaac J. Helmericks

nesting as far east as Kamchatka, is migratory, however, wintering south to Ussuriland, Manchuria, Sakhalin, and Honshu (Vaurie 1959, Brazil 2009).

The winter of 2011-2012 turned very cold in early December; low temperatures fell as low as $-20^{\circ} \mathrm{C}$, whereas the average low temperature at Adak in December is $-1^{\circ} \mathrm{C}$. On 30 December the low was $-13^{\circ} \mathrm{C}$, the high $-4^{\circ} \mathrm{C}$. The winter produced the heaviest snow accumulation I experienced during my five years at Adak from 2007 to 2012. All fresh water was frozen, and $30-36 \mathrm{~cm}$ of snow covered the ground down to the high tide line, with deeper drifts in places. The roads out of town had been impassable for several weeks, and it was only on 30 December that

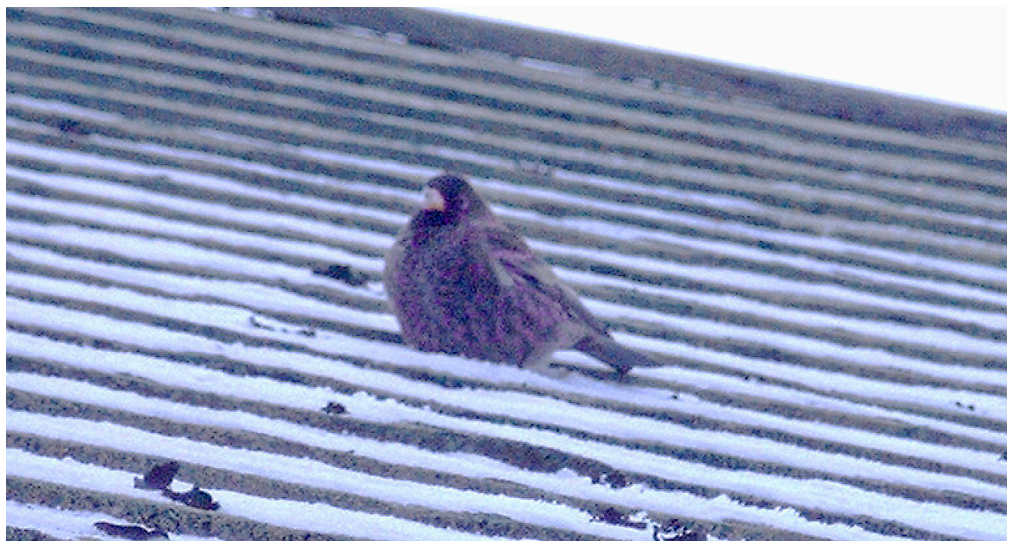

Figure 4. Asian Rosy-Finch at Gambell, St. Lawrence Island, Alaska, 26 October 2008. 


\section{NOTES}

I was able to get out the road between town and Clam Lagoon, part of one of my standard transects. Thus I had not been in that area for some time when I located the small flock that included the Asian Rosy-Finch. The heavy snow accumulation also hampered my efforts to try to relocate the bird in the days after the sighting, and it was not seen again. Of interest in this context are Aleutian records of other vagrant passerines surfacing in the middle of hard winters with periods of heavy snow-e.g., a male Eurasian Bullfinch (Pyrrhula pyrrhula cassinii) and Pine Grosbeaks (probably Pinicola enucleator flammula) photographed at Unalaska Island in January 2012 (S. Golodoff, in litt., 2012) and additional Pine Grosbeaks I photographed at Adak in December 2011. In other winters, I saw at Adak a White Wagtail (Motacilla alba lugens) in December 2008 and January 2009 and a flock of three Bramblings (Fringilla montifringilla) and a single Eyebrowed Thrush (Turdus obscurus) in January 2014. All of these taxa are well known in the Aleutians at other seasons (see Gibson and Byrd 2007), but their occurrences in midwinter make one wonder just how far, and from where, such birds might have flown to surface where and when they did.

I recognize Daniel D. Gibson for his invaluable editorial advice and review. Additionally, I thank Kimball L. Garrett for his thoughtful review of this paper.

\section{LITERATURE CITED}

Brazil, M. 2009. Field Guide to the Birds of East Asia. Christopher Helm, London.

Clement, P., and Arkhipov, V. 2017. Asian Rosy-Finch (Leucosticte arctoa), in Handbook of the Birds of the World Alive (J. del Hoyo, A. Elliott, J. Sargatal, D. A. Christie, and E. de Juana, eds.). Lynx Edicions, Barcelona.

Dickinson, E. C., and Christidis, L. (eds.). 2014. The Howard and Moore Complete Checklist of the Birds of the World, 4th ed. Vol. 2: passerines. Aves Press, Eastbourne, England.

Gibson, D. D., and Byrd, G. V. 2007. Birds of the Aleutian Islands, Alaska. Nuttall Ornithol. Club and Am. Ornithol. Union Series Ornithol. 1.

Gibson, D. D., DeCicco, L. H., Gill, R. E. Jr., Heinl, S. C., Lang, A. J., Tobish, T. G. Jr., and Withrow, J. J. 2013. Third report of the Alaska Checklist Committee, 2008-2012. W. Birds 44:183-195.

Kessel, B. 1989. Birds of the Seward Peninsula, Alaska: Their Biogeography, Seasonality, and Natural History. Univ. Alaska Press, Fairbanks.

Vaurie, C. 1959. The Birds of the Palearctic Fauna. Passeriformes. H. F. \& G. Witherby, London.

Accepted 8 April 2017 